\title{
Sessile oak (Quercus petraea Liebl.) site index variations in relation to climate, topography and soil in even-aged high-forest stands in northern France
}

\author{
Laurent BERGÈS $^{\mathrm{a} *}$, Richard CHEVALIER ${ }^{\mathrm{a}}$, Yann DUMAS ${ }^{\mathrm{a}}$, Alain FRANC ${ }^{\mathrm{b}}$, Jean-Michel GILBERT ${ }^{\mathrm{c}}$ \\ ${ }^{a}$ Cemagref, Forest Ecosystems Research Unit, Domaine des Barres, 45290 Nogent-sur-Vernisson, France \\ b INRA, Département Ecologie des Forêts, Prairies et Milieux Aquatiques, CDA UMR Biodiversité, Gènes et Écosystèmes, \\ 69 route d'Arcachon, Pierroton, 33612 Cestas Cedex, France \\ ${ }^{c}$ Ministère de l'Agriculture, de l'Alimentation, de la Pêche et de la Ruralité, Direction Générale de la Forêt et des Affaires Rurales, \\ 19 avenue du Maine, 75732 Paris Cedex 1507 SP, France
}

(Received 5 April 2004; accepted 2 March 2005)

\begin{abstract}
The relationships between $Q$. petraea site index and site variables were studied using data from 99 even-aged high-forest stands located in north-western and north-eastern France. Stepwise multiple regressions using climate, topography and soil factors were adjusted and explain 49 to $60 \%$ of the variance in site index. This clearly demonstrates that an autecological study can be successfully performed over a large geographical area if an appropriate sampling strategy is applied. Moreover, the autecology of sessile oak was specified: (1) the role of soil water capacity, topographic position, $\log (\mathrm{Mg}), \log (\mathrm{S}), \mathrm{K} / \mathrm{P}_{2} \mathrm{O}_{5}, \mathrm{Mg} / \mathrm{K}$ and humus form was emphasized; (2) no regional differences in site index were observed, which was corroborated by few climatic effects; (3) models adjusted to each region were consistent; (4) nutrient factors explained a higher portion of variance of $Q$. petraea site index compared to climate/water-related factors, however the confounding effect was significant.
\end{abstract}

site index / ecological factors / soil analyses / Quercus petraea (Mattus) Liebl.

Résumé - Variations de l'indice de fertilité du chêne sessile (Quercus petraea Liebl.) en fonction du climat, de la topographie et du sol dans des futaies régulières adultes du nord de la France. Les relations entre l'indice de fertilité de $Q$. petraea et le milieu ont été étudiées dans 99 peuplements de futaies régulières adultes du centre-ouest et nord-est de la France. Des régressions multiples pas à pas basées sur le climat, la topographie et le sol expliquent de 49 à $60 \%$ de la variance de l'indice de fertilité. Ce résultat indique clairement qu'une étude autécologique peut être menée avec succès sur un grand secteur géographique si une stratégie d'échantillonnage adaptée est appliquée. De plus, l'autécologie du chêne sessile est précisée : (1) nous soulignons le rôle de la réserve utile en eau du sol, de la position topographique, de log(Mg), $\log (\mathrm{S}), \mathrm{K} / \mathrm{P}_{2} \mathrm{O}_{5}, \mathrm{Mg} / \mathrm{K}$ et du type d'humus sur l'indice de fertilité ; (2) aucune différence inter-régionale n'est observée sur l'indice de fertilité, ce qui est corroboré par le faible effet du climat sur la croissance ; (3) les modèles prédictifs ajustés au niveau de chaque région sont très proches ; (4) la part de variance de l'indice de fertilité expliquée par le niveau trophique est plus élevée que celle liée aux facteurs hydriques et climatiques, mais la part commune expliquée par ces trois facteurs est importante.

indice de fertilité / facteurs écologiques / analyses de sol / Quercus petraea (Mattus) Liebl.

\section{INTRODUCTION}

The potential productivity in various site conditions is one of the most important criteria for decision making in forest management [49]; it allows the forester to select the most suitable crop species, to precisely forecast stand production and to make species-specific and site-specific silvicultural prescriptions (rotation age, intensity and frequency of thinnings) [48]. Knowledge of the species response to site conditions could help identify particular sites on which the species is or may become unsuitable, especially in the context of climate warming and/or nitrogen deposition.

Potential productivity for a given species has been widely assessed by site index measurement, defined as the top height of dominant trees at a reference age for forest stands which are regular, even-aged, pure and closed [34].

Systems for evaluating site quality and predicting forest productivity based on site-growth relationships have received considerable attention over the past 50 years [64]. Numerous studies, known as soil-site studies, have focused on predicting site index in various ecological conditions and forest species $[22,25]$.

In France, most of these studies are being criticised because they have not provided enough precise results in spite of their relatively high cost. The main drawback is that a large variability can persist within forest site types in a study which relates site index to a pre-established forest site type classification

* Corresponding author: laurent.berges@cemagref.fr 
(= synoptic approach). This variability may be related to the heterogeneity of the soil water capacity within the site types [29]. But when sampling data are stratified according to soil water capacity, the precision of the results delivered with a synoptic approach can be as good as with an analytical approach that directly links ecological descriptors to site index [29].

The quality of the results mainly depends on 4 factors: (1) the species' ecological range, which determines the magnitude of the response to site variations; (2) the sampling strategy applied (an extended range of forest site types, equal sampling in each forest site type or regular distribution along the ecological gradients is recommended), (3) the stand selection (stands must follow Eichhorn's rule) [34] and (4) the quality of the collected data.

The problem of spatial scale has also been widely discussed [21]. Most of the studies on tree species in lowland forests have been restricted to small regions where climatic variability is reduced. Only a few studies cover large regions [29, 38, 51]. More accurate results are expected if studies are restricted to small areas with little climatic and geomorphologic variability and understory vegetation is used to diagnose site quality. However, restricting the study to a small, climatically uniform region is questionable when site diagnosis is not based on understory layer [35] or when the study is located in mountainous regions where altitude, aspect and topography are the main ecological gradients [10, 29]. Indeed, most of the studies have limited success in accounting for site index variation over large areas $[23,66]$. In addition, only a few test the hypothesis that enlargement of the study area could cause a decrease in site index prediction quality [23, 29].

Sessile oak (Quercus petraea Liebl.) is the most widespread and important deciduous timber species in France; together with pedunculate oak ( $Q$. robur L.), it represents $30.5 \%$ of the forest surface and $28 \%$ of the standing volume [44]. Sessile oak has adapted to a large range of ecological conditions. It displays a different, larger ecological amplitude compared to pedunculate oak: it is less nutrient-demanding, more tolerant to drought but less tolerant to the presence of calcium carbonate in soils $[8,17,26,42,65]$. Young sessile oaks are less tolerant to waterlogging in the soil than pedunculate oaks; however, adult sessile oaks show a better growth in waterlogged soils that are frequently exposed to summer drought, because drought is a more limiting factor than watterlogging for pedunculate oaks [58]. Recent studies have been restricted to particular forests or small natural regions [20, 46], except for one in north-western France which focused on radial growth [56]. Most of them have been carried out by students from the French Forest Engineering School (ENITEF) but have not been published in French or international journals. An extrapolation of the results to a large area, a clarification of the role of the climate, soil water regime and nutrient richness in predicting sessile oak growth and an estimate of the magnitude of their effects [41] are necessary.

The objectives of this study are: (1) to test the feasibility of a study on the relationships between site index and ecological factors over a large territory ( 550 by $250 \mathrm{~km})$, i.e., 9 "départements" and 12 "régions IFN" and (2) to quantify the respective effects of radiation, water and nutrient budgets on sessile oak site index.
Our hypothesis is that accurate site index predictions can be made even if the study area is large if the following rules are respected: (1) to cross soil water content and nutrient status in a balanced sampling design, (2) to sample regularly along these ecological gradients and especially in edges and (3) to collect high-quality ecological indices.

\section{MATERIALS AND METHODS}

\subsection{Sampling strategy and study area}

In order to accurately analyse the relationships between ecological parameters and growth variables, we chose to use an analytical approach [40] and to precisely assess the three main budgets for wood production: radiation, water and nutrients [28]. However, this does not mean that these budgets are easy to estimate (for example, numerous input parameters - climatic, topographic and soil - are required to estimate water budget). As recommended by Franc and Houllier [34], a sampling strategy was defined to: (1) explore the largest site variations possible regarding soil water capacity and mineral nutrient conditions; (2) respect an orthogonal sampling plan, i.e., a complete, balanced twofactor plan for soil water and mineral richness which would allow a proper estimation of the main effects and their interaction and (3) limit the effects of other factors, especially those related to silvicultural practises; we only sampled adult ( $>60$ years), nearly pure, even-aged, closed, high-forest stands of oaks grown from seedlings. Stands were selected according to official information on the origin of the stand (seedling or sprout) in the forest management plan (if available) and/ or by observing stem form (absence of twin stems within the stand). However, in order to find site conditions that were infrequent but necessary for statistical analyses, some variation in purity and even-age characteristics of the oak stands was accepted. In this case, at least $60 \%$ of the dominant trees were either sessile or pedunculate oaks (the normal criterion was $80 \%$ ) and the age variation of the dominant trees was less than $10 \%$ of the mean age [31]. Height plots did not meet this last condition but were retained because of particular site conditions.

The general study area partly covers the South-east of the Paris Basin and the North-east of France. Within this area, a previous climatic analysis published by Gilbert and Franc [39] helped us to define two distinct, climatically homogeneous regions using relative annual water budgets (see Fig. 1): the eastern region where the annual water deficit was under 15\% ("Lorraine" and "Alsace" administrative "Régions", "Alsace Plain" excluded), and the western region where the annual water deficit was over $15 \%$ ("Centre" and "Pays-de-Loire" Régions). Despite this climatic stratification, moderate climatic variations remained within the study area. The calculation for the annual water deficit is detailed in Gilbert and Franc [39] who used climatic means for the 1961-1990 period from the French meteorological stations network. The water balance model is based on the following algorithm where PET: potential evapotranspiration, AET: actual evapotranspiration, P: precipitation and SWC: soil water capacity. Monthly potential evapotranspiration (PETm) is calculated using Thornthwaite or Turc's formula. If Pm $\geq$ PETm then AETm $=$ PETm. If $\mathrm{Pm}<\mathrm{PETm}$ then soil water reserve is used and the amount of water collected is a function of the water deficit accumulated over the previous months: in this case, $\mathrm{AETm}=\mathrm{Pm}+\mathrm{P}_{\mathrm{SWC}} \mathrm{m}$, where $\mathrm{P}_{\mathrm{SWC}}$ is the portion of the soil water capacity that is collected. When the period of water deficit is finished, the extra-water not transpired by the plant is used first to reconstitute the soil water reserve, then is flown out of the system. Finally, the annual soil water deficit is computed as follows:

$$
\sum_{m=1}^{12} \frac{(\text { AETm-PETm })}{\text { PETm }}
$$




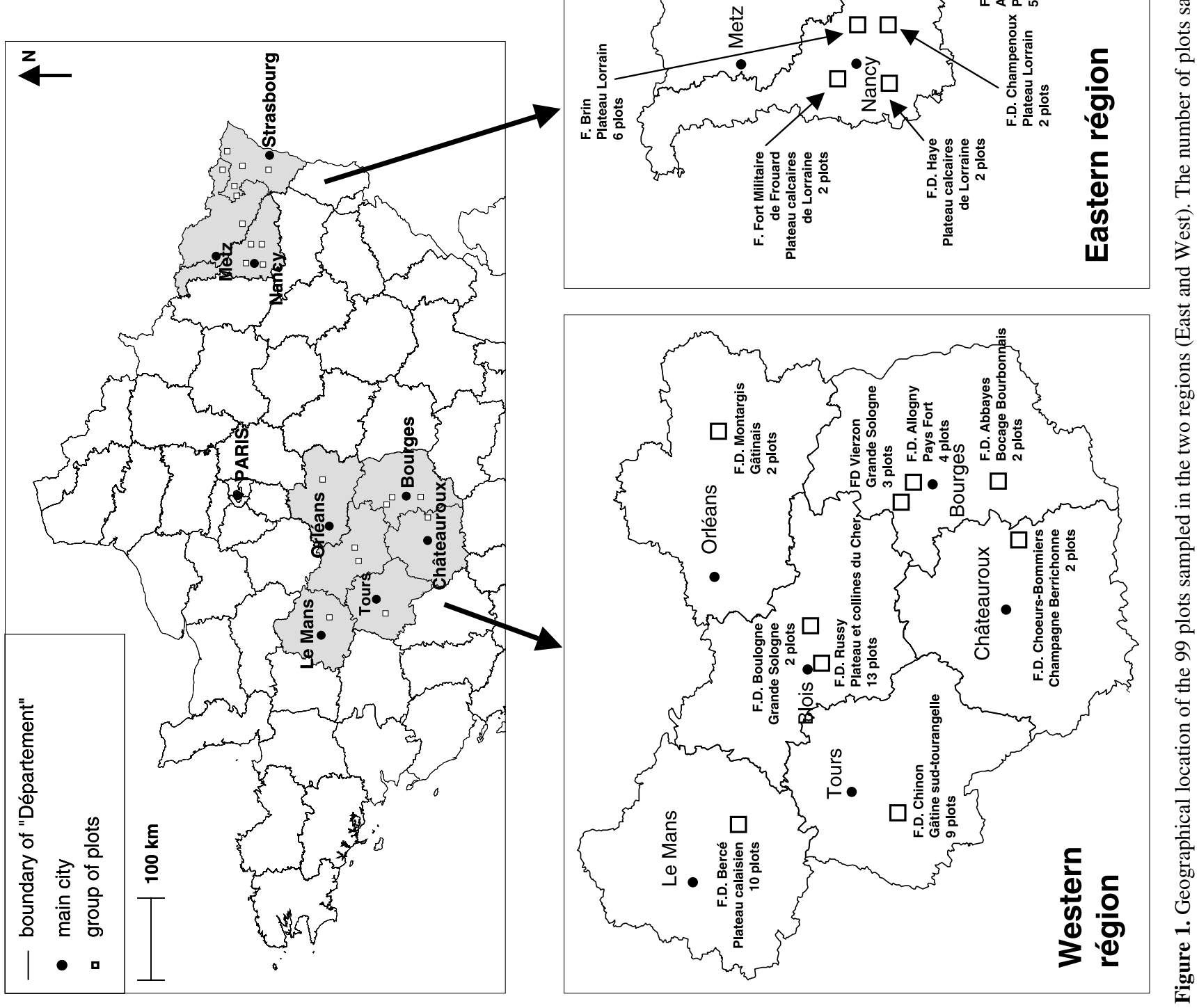


The following site factors were fixed or controlled during field operations: the upper altitudinal limit was fixed at $500 \mathrm{~m}$ (the northern "Vosges" mountains were the highest points); waterlogged conditions were controlled and we only selected stands where (1) temporary waterlogging below $50 \mathrm{~cm}$ was present whatever the intensity of the gleyed layer discoloration or (2) temporary waterlogging above $50 \mathrm{~cm}$ was present but with very moderate gleyed layer discoloration. Other ecological factors (topographic position, aspect, parent material, soil texture and type) were not stratified but only measured; this allowed us to test their effect on tree growth.

Though the final sampling design was composed of 99 plots, it was incomplete and unbalanced. More precise measurements were done on these 99 plots.

\subsection{Site index measurement}

Twenty-meter-radius circular plots ( 0.126 ha) were set up within homogeneous site conditions following Brêthes' recommendations [21]. When site conditions were not sufficiently homogeneous, the sample plot area was reduced to 0.07 ha (a 15-m-radius circular plot or rectangle).

Dominant height $\left(\mathrm{H}_{0}\right)$ was measured using a variant of Duplat's protocol [31] that is normally based on the measurement of the 1st, 3 rd and 5th biggest trees on a 0.06-ha plot to estimate the mean height of the 100 biggest trees per ha. We identified the 6 biggest trees in the circular plot and randomly chose 3 oaks among the following 3 couples: 1 st and 2 nd, 3rd and 4th and 5th and 6th. This provided an estimate of the mean height of the population which approached the 50 biggest trees per ha. We chose one tree in each couple as a compromise between systematic selection and to avoid coring very highquality trees. The total height of each tree was estimated from two opposite sides at a variable distance from the tree by measuring angular characteristics with a clinometer. Tree height measurement error was less than $0.7 \mathrm{~m}$. Each tree was cored twice to the pith with a 5-mm Pressler corer at a height of 1 and $1.10 \mathrm{~m}$. Cores were made in the same direction to ensure a very short distance from the pith. Following Duplat and Tran-Ha's recommendations [30], 4 years were added to the age counted on the best increment core to obtain a tree age at $0.30 \mathrm{~m}$ height. The height and age of the 3 measured trees were averaged to assess plot dominant height $\left(\mathrm{H}_{0}\right)$ and mean age. Site index was computed with a reference age of 100 years (called SI $_{100}$ below) using height-age curves (model B) from Duplat and Tran-Ha [30] (Fig. 2).

\subsection{Climate and soil data collection}

Monthly median precipitation and mean temperature for the 19611990 period were provided by Meteo France and came from two databases: (1) for 36 eastern plots, digitised data from thematic maps (AURELHY method) with a resolution of $1 \mathrm{~km}^{2}$; (2) for the remaining 16 eastern plots, data came from 5 stations for precipitation and 2 stations for temperature and for the 47 western plots, data came from 5 stations for temperature and from 13 stations for precipitation. Several climatic indices were computed (see Tab. I).

Topographic characteristics, elevation, slope, aspect, topographic position and parent material were measured in the field or collected on suitable maps. Humus form was described in three different locations according to the Pedological Reference frame classification [45]. According to Llyod et Lemmon [60] aspect was transformed into a continuous variable for plots where aspect was over $4 \%$ using the following formula: Aspect $=\cos (\mathrm{RA}-\mathrm{A})$, where $\mathrm{A}$ is the plot azimuth and $\mathrm{RA}$ is a given reference azimuth (in grades); Aspect $=1$ if $\mathrm{A}=\mathrm{RA}$ and -1 if $A=R A \pm 200$; a value of 0 for Aspect was assigned to plots where slope was less than $4 \%$. The RA is known to be between north and east $[6,60]$ and was optimised for our data by calculating the maximum correlation between $\mathrm{SI}_{100}$ and Aspect: it was 75 gr.

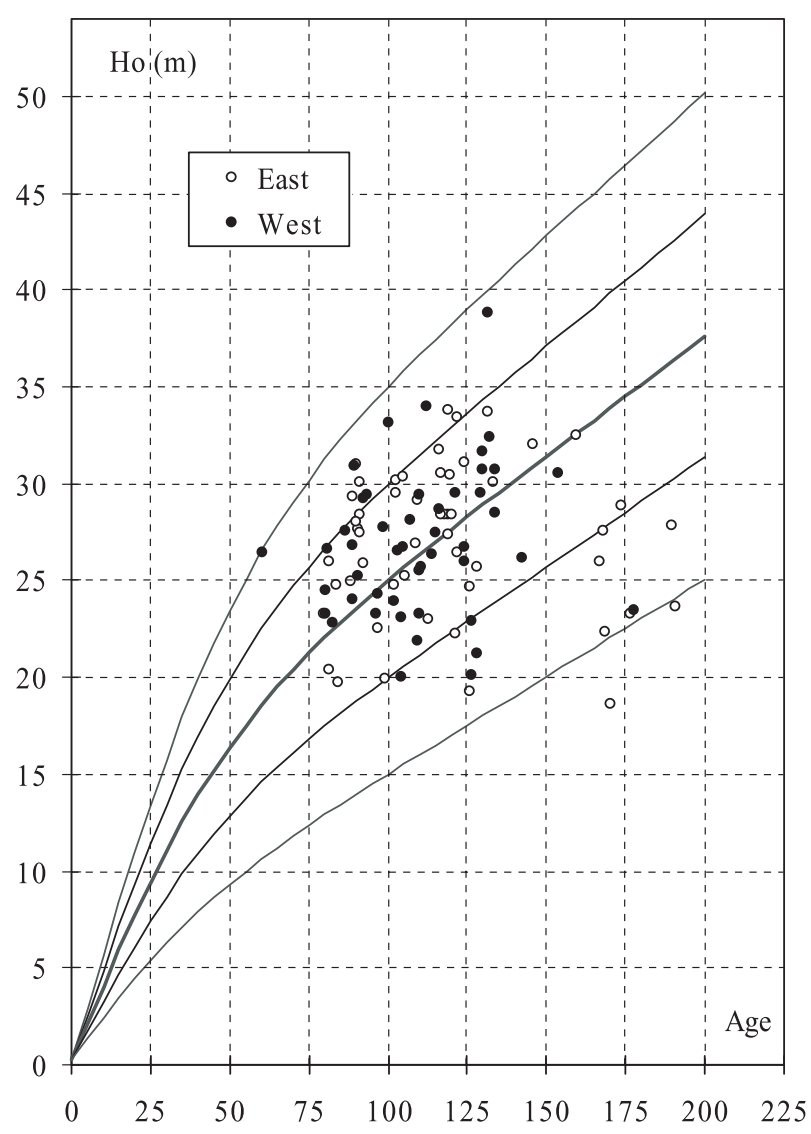

Figure 2. Modelisation of sessile oak dominant height as a function of stand age according to model B of Duplat and Tran-Ha [30]. Simulation of $\mathrm{H}_{0}$ as a function of age for 5 site indices at the reference age of 100 years $(15,20,25,30$ and $35 \mathrm{~m})$ and data observed (East and West samples).

A soil pit, $2 \mathrm{~m}$ in depth, was excavated with a mechanical shovel at a distance of $3 \mathrm{~m}$ from one of the cored trees. Digging was continued until an R-horizon (bedrock) was reached. Two plots were dug manually because access for the shovel was impossible: these two plots had very shallow soil. Soil profile was described using a standard protocol, which included observations on the intensity and location of an $\mathrm{HCl}$ effervescence (localised or generalised effervescence of the fine soil fraction), size and percentage of coarse elements, soil drainage assessed by hydromorphic mottling using Baize and Jabiol's classification [2].

In order to carry out complementary physical and chemical analyses, A-horizon soil samples were collected in 5 locations within the plot. Soil samples were air-dried, then sieved at $2 \mathrm{~mm}$. Soil particle size distribution was determined on mineral horizons using the hydrometer method. The following chemical analyses were performed according to recommendations from Gégout and Jabiol [37]: $\mathrm{pH}-\mathrm{H}_{2} \mathrm{O}$, $\mathrm{pH}-\mathrm{KCl} 1 \mathrm{~N}$, cationic exchangeable capacity at soil $\mathrm{pH}$, exchangeable $\mathrm{Ca}, \mathrm{Mg}, \mathrm{K}, \mathrm{Al}$ and $\mathrm{H}^{+}$, total organic carbon $\mathrm{C}$, total organic nitrogen $\mathrm{N}$ and potentially available phosphorous. Analytical results were expressed as concentrations over dry-mass $\left(\mathrm{cmol}^{+} / \mathrm{kg}\right.$ for cations and $\mathrm{g} / \mathrm{kg}$ for $\mathrm{C}, \mathrm{N}$ and $\mathrm{P}_{2} \mathrm{O}_{5}$ ). Saturation rate of the absorbing complex, $\mathrm{C} / \mathrm{N}$ ratio and several mineral element content ratios identified as important for tree nutrition were also calculated [15]. 
Table I. Elementary statistics of forest mensuration and ecological data (see text for further explanation for variable description and computation). Ecological data are separated into climatic and soil data. Chemical data were measured in the A-horizon. The different classes used are provided and the number of plots per class are mentioned between brackets.

\begin{tabular}{|c|c|c|c|c|c|c|}
\hline Variable name and unit & Code & Min & $\begin{array}{c}\text { Total } \\
\text { Mean } \pm \text { SD }\end{array}$ & Max & $\begin{array}{c}\text { Eastern region } \\
\text { Mean } \pm \mathrm{SD}\end{array}$ & $\begin{array}{l}\text { Western region } \\
\text { Mean }( \pm \mathrm{SD})\end{array}$ \\
\hline Number of plots & & & $n=99$ & & $n=52$ & $n=47$ \\
\hline \multicolumn{7}{|l|}{ Stand characteristics } \\
\hline Age (at $0.30 \mathrm{~m}$ ) & Age & 56 & $110.7 \pm 26.6$ & 187 & $114.8 \pm 30.0$ & $106.2 \pm 21.8$ \\
\hline Site index at 100 years $(\mathrm{m})$ & $\mathrm{SI}_{100}$ & 12.1 & $25.3 \pm 4.6$ & 34.8 & $24.9 \pm 4.9$ & $25.8 \pm 4.2$ \\
\hline Basal area at $1.30 \mathrm{~m}\left(\mathrm{~m}^{2} / \mathrm{ha}\right)$ & G & 13.1 & $27.2 \pm 6.3$ & 53.3 & $27.4 \pm 6.8$ & $27.1 \pm 5.8$ \\
\hline \multicolumn{7}{|l|}{ Climatic data } \\
\hline Mean annual temperature $\left({ }^{\circ} \mathrm{C}\right)$ & MAT & 8.4 & $10.0 \pm 1.0$ & 11.1 & $9.1 \pm 0.4$ & $11.1 \pm 0.1$ \\
\hline Median annual precipitation (mm) & MAP & 644 & $793 \pm 114$ & 1008 & $881 \pm 80$ & $695 \pm 40$ \\
\hline PET-P from April to October (mm) & PET-P & 53.0 & $115.0 \pm 42.1$ & 199.0 & $81.7 \pm 25.8$ & $152 \pm 20$ \\
\hline Soil water deficit (mm) & SWD & 11.4 & $68.3 \pm 45.8$ & 181.5 & $30.8 \pm 17.4$ & $109.7 \pm 28.2$ \\
\hline Altitude (m) & Altitude & 85 & $224 \pm 109$ & 476 & $314 \pm 68$ & $124 \pm 32$ \\
\hline Aspect (after cos transformation) & Aspect & -1.00 & $-0.02 \pm 0.53$ & 1.00 & $-0.02 \pm 0.59$ & $-0.02 \pm 0.46$ \\
\hline $\begin{array}{l}\text { Topographic position ( } 3 \text { classes with } \\
\text { L: lateral loss; G: lateral gain) }\end{array}$ & Topo & \multicolumn{3}{|c|}{$\begin{array}{c}\mathrm{L}>\mathrm{G}(n=13) ; \mathrm{G}=\mathrm{L}(n=75) ; \\
\mathrm{G}>\mathrm{L}(n=11)\end{array}$} & $\begin{array}{c}\mathrm{L}>\mathrm{G}(n=10) ; \mathrm{G}=\mathrm{L}(n=34) ; \\
\mathrm{G}>\mathrm{L}(n=8)\end{array}$ & $\begin{array}{c}\mathrm{L}>\mathrm{G}(n=3) ; \mathrm{G}=\mathrm{L} \\
(n=41) ; \mathrm{G}>\mathrm{L}(n=3)\end{array}$ \\
\hline \multicolumn{7}{|l|}{ Physical and chemical soil properties } \\
\hline Soil depth $(\mathrm{cm})$ & SD & 35 & $159 \pm 38$ & 200 & $156 \pm 48$ & $162 \pm 25$ \\
\hline Stone content $(\%)$ & SC $0-150$ & 0 & $28.6 \pm 24.5$ & 91.0 & $21.3 \pm 24.3$ & $36.7 \pm 22.3$ \\
\hline Soil water capacity on $150 \mathrm{~cm}(\mathrm{~mm})$ & SWC $0-150$ & 5 & $153 \pm 69.7$ & 275 & $156 \pm 81$ & $149 \pm 56$ \\
\hline $\mathrm{pH}-\mathrm{H}_{2} \mathrm{O}$ & $\mathrm{pH}-\mathrm{H}_{2} \mathrm{O}$ & 3.94 & $4.69 \pm 0.66$ & 7.13 & $4.76 \pm 0.58$ & $4.60 \pm 0.74$ \\
\hline $\mathrm{pH}-\mathrm{KCl} 1 \mathrm{~N}$ & $\mathrm{pH}-\mathrm{KCl}$ & 2.80 & $3.72 \pm 0.75$ & 6.28 & $3.77 \pm 0.68$ & $3.66 \pm 0.82$ \\
\hline Exchangeable calcium $\left(\mathrm{cmol}^{+} / \mathrm{kg}\right)$ & $\mathrm{Ca}$ & 0.07 & $4.86 \pm 8.36$ & 47.00 & $4.95 \pm 8.12$ & $4.76 \pm 8.71$ \\
\hline Exchangeable magnesium $\left(\mathrm{cmol}^{+} / \mathrm{kg}\right)$ & $\mathrm{Mg}$ & 0.05 & $0.92 \pm 0.91$ & 5.44 & $0.85 \pm 1.04$ & $1.00 \pm 0.75$ \\
\hline Exchangeable potassium $\left(\mathrm{cmol}^{+} / \mathrm{kg}\right)$ & $\mathrm{K}$ & 0.07 & $0.35 \pm 0.23$ & 1.08 & $0.37 \pm 0.27$ & $0.32 \pm 0.16$ \\
\hline Exchangeable base sum $\left(\mathrm{cmol}^{+} / \mathrm{kg}\right)$ & $S$ & 0.20 & $6.13 \pm 9.08$ & 49.83 & $6.17 \pm 9.00$ & $6.08 \pm 9.27$ \\
\hline Exchangeable proton $\left(\mathrm{cmol}^{+} / \mathrm{kg}\right)$ & $\mathrm{H}^{+}$ & 0.05 & $1.08 \pm 1.01$ & 5.28 & $0.74 \pm 0.50$ & $1.47 \pm 1.28$ \\
\hline Exchangeable aluminium $\left(\mathrm{cmol}^{+} / \mathrm{kg}\right)$ & $\mathrm{Al}$ & 0.05 & $1.54 \pm 1.37$ & 7.68 & $1.58 \pm 1.29$ & $1.50 \pm 1.47$ \\
\hline Cationic exchange capacity $\left(\mathrm{cmol}^{+} / \mathrm{kg}\right)$ & CEC & 2.22 & $10.20 \pm 9.71$ & 57.62 & $9.99 \pm 9.60$ & $10.43 \pm 9.93$ \\
\hline Saturation rate $(\%)$ & $\mathrm{S} / \mathrm{T}$ & 4.7 & $50.4 \pm 32.8$ & 100 & $47.7 \pm 34.6$ & $53.5 \pm 31.1$ \\
\hline Organic carbon $(\mathrm{g} / \mathrm{kg})$ & $\mathrm{C}$ & 17.1 & $58.4 \pm 37.5$ & 236.9 & $42.6 \pm 14.8$ & $75.8 \pm 46.6$ \\
\hline Nitrogen $(\mathrm{g} / \mathrm{kg})$ & $\mathrm{N}$ & 0.91 & $3.30 \pm 1.67$ & 10.25 & $2.78 \pm 1.09$ & $3.88 \pm 2.00$ \\
\hline $\mathrm{C} / \mathrm{N}$ & $\mathrm{C} / \mathrm{N}$ & 8.52 & $17.47 \pm 4.61$ & 37.55 & $16.05 \pm 3.96$ & $19.06 \pm 4.80$ \\
\hline Phosphorous (g/kg) & $\mathrm{P}_{2} \mathrm{O}_{5}$ & 0.02 & $0.13 \pm 0.11$ & 0.82 & $0.16 \pm 0.15$ & $0.10 \pm 0.04$ \\
\hline Humus form (5 classes) & Humus & \multicolumn{3}{|c|}{$\begin{array}{l}\text { 1- Dysmoder-Mor }(n=25) ; 2 \text { - Eumoder } \\
(n=16) ; 3 \text { - Oligomull to Hemimoder } \\
(n=22) ; \text { 4- Mesomull }(n=13) ; \\
\text { 5- Eumull }(n=23)\end{array}$} & $\begin{array}{c}1(n=7) ; 2(n=6) ; 3(n=15) \\
4(n=4) ; 5(n=20)\end{array}$ & $\begin{array}{c}1(n=18) ; 2(n=10) \\
3(n=7) ; 4(n=9) \\
5(n=3)\end{array}$ \\
\hline
\end{tabular}

Soil water capacity, i.e., plant-available water between field capacity and the permanent wilting point, was calculated using Jamagne's coefficients [47] and the classic formula given by Lévy [59]. C, M, R and D-horizons also contain a small quantity of water that was taken into account only if fine roots were observed in the horizons. We used specific, arbitrary coefficients for the $\mathrm{C}$-horizon of granite arenas $(0.6 \mathrm{~mm} / \mathrm{cm}), \mathrm{Mn}$-horizons of $\operatorname{marl}(0.5 \mathrm{~mm} / \mathrm{cm})$ and R-horizon of soft sandstone $(0.2 \mathrm{~mm} / \mathrm{cm})$.

\subsection{Data analysis methods}

The effect of SWC, climate and soil nutrients on site index were first analysed using ANOVA, linear or polynomial regressions. This allowed us to detect the nature of the relationship between site index and explanatory variables. Then, stepwise multiple regressions were used to test the additive effects of these factors. Models were adjusted to each regional sample then to the whole sample. Specific two-way 
ANOVA were also adjusted to test the interaction between soil water and nutrient-related factors. Variance homogeneity and distribution of residuals were visually checked.

Multiple regression fitting was followed by variance partition using Type I sum of squares, which allows the respective parts of the 3 basic budgets (climate, water and nutrients) and the confounding part of these factors to be quantified. The variables were clustered into 2 groups: climate/water-related and nutrient-related factors. The models were successively fitted (1) with first the climate/water group and second the nutrients group entered into the model (2) then the contrary.

ANOVA, simple and multiple stepwise regressions were performed using S-plus version $6.2^{\circledR}$.

\section{RESULTS}

\subsection{Sampling characteristics}

Elementary statistics for forest mensuration, climate and soil variables are presented in Table I. The 8 basic humus forms were grouped into 5 simplified classes for analysis purposes. Plot age distribution was dispersed but $84 \%$ of the plots were 80 to 130 years old (Fig. 2). Site index was more variable compared to Duplat and Tran-Ha's observations [30]: these authors indicated that site index at 100 years varied between 15.1 and $30.7 \mathrm{~m}$ and plot age varied between 102 and 216 years. The comparison of the two samples was not rigorous because age ranges were not similar in both data sets. However, minimum $\mathrm{SI}_{100}$ corresponded to the same ages. After eliminating the youngest plots (the maximum $\mathrm{SI}_{100}$ was $34.8 \mathrm{~m}$ for a 56-yearold plot), maximum site index was higher compared to Duplat and Tran-Ha's sample [30] because a 135-year-old plot with $\mathrm{SI}_{100}=33.9 \mathrm{~m}$ was included. The lowest $\mathrm{SI}_{100}$ in our sample corresponded to extremely poor site conditions not sampled by Duplat et Tran-Ha [30].

\subsection{Relationships between site index and ecological variables}

\subsubsection{Role of soil water capacity and topographic position}

$\mathrm{SI}_{100}$ was correlated with SWC (Tab. II). Complementary analyses not presented here allowed us to keep the SWC computed to a depth of $150 \mathrm{~cm}$ (called below SWC 0-150) as the $\mathrm{SWC}$ reference value in the next analyses. $\mathrm{SI}_{100}$ increased by $3.2 \mathrm{~m}$ when SWC 0-150 increased by $100 \mathrm{~mm}$.

$\mathrm{SI}_{100}$ was correlated with topography (Tab. II): compared to neutral positions $($ gain $=$ loss $)$, site index was reduced $(-3.8 \mathrm{~m})$ in deficit positions (loss $>$ gain) whereas it increased $(+2.7 \mathrm{~m})$ in favourable positions (gain $>$ loss).

\subsubsection{Role of climatic factors, water balance and soil water deficit}

Aspect had an effect on site index, but the effect is more significant if only plots where slope was over or equal to $4 \%$ were kept (Tab. II): site index was reduced $(-2.9 \mathrm{~m})$ when aspect was $275 \mathrm{gr}$ and it increased (+2.9 m) when aspect was $75 \mathrm{gr}$, compared to neutral aspects (175 or 375 gr). However, precipita-

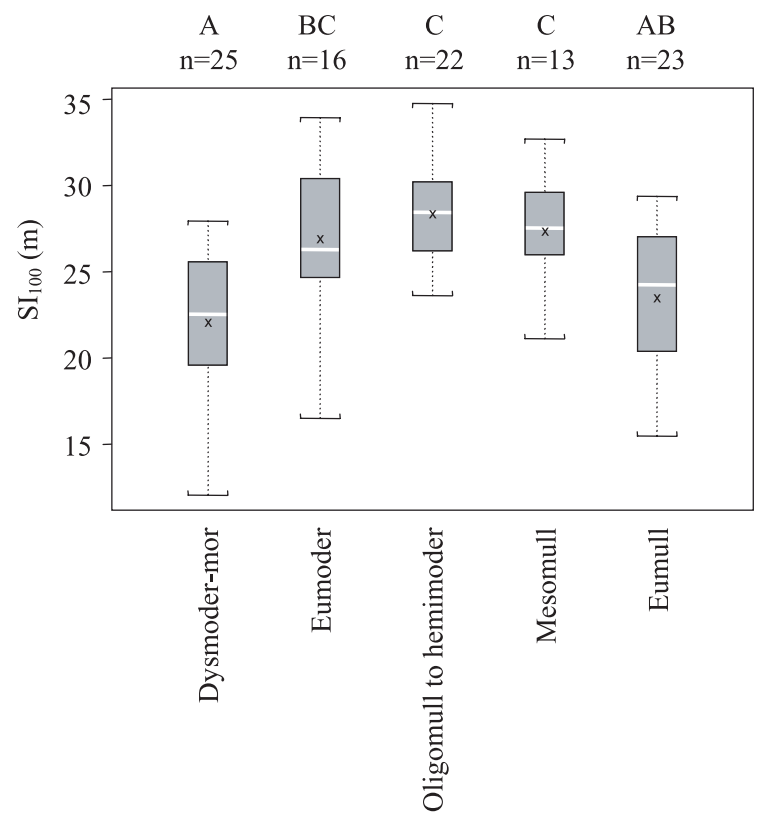

Figure 3. Boxplot of site index ( $\left.\mathrm{SI}_{100}\right)$ according to humus form: the thick horizontal line within the box corresponds to the median and the cross corresponds to the mean; the letter above each class indicates the result of pairwise multiple comparisons (Tukey method).

tion, temperature, altitude, PET-P or SWD had no significant effect on $\mathrm{SI}_{100}$.

\subsubsection{Role of nutrient richness}

Humus form had a strong effect on $\mathrm{SI}_{100}(31 \%$ of the variance explained): growth was low on extreme humus forms (eumull and dysmoder-mor) and high on oligomull-to-hemimoder, but no significant differences were found between mesomull, eumoder and oligomull-to-hemimoder (Fig. 3).

Simple or polynomial regressions were fitted after graphical observation of $\mathrm{SI}_{100}=\mathrm{f}(\mathrm{X})$ and after $\log$ transformation for exchangeable cations (Tab. II). The relationship between $\mathrm{SI}_{100}$ and $\mathrm{S} / \mathrm{T}, \mathrm{pH}-\mathrm{KCl}$ or $\mathrm{pH}-\mathrm{H}_{2} \mathrm{O}$ was parabolic, with an optimum value around $50 \%$ for $\mathrm{S} / \mathrm{T}$.

According to the threshold values provided by Bonneau [15], the proportion of plots low in $\mathrm{K}$ and $\mathrm{Ca}$ was large but this was less important for $\mathrm{Mg}$. More than $50 \%$ of the eastern plots and about $75 \%$ of the western plots were K-deficient. But the percentage of plots where $\mathrm{Ca}$ and $\mathrm{Mg}$ were deficient or in excess was similar in both regions. The comparison to threshold values that correspond to analysis at $\mathrm{pH}=7$ was correct because soil measurement at $\mathrm{pH}=7$ does not overestimate real exchangeable $\mathrm{Mg}$ and $\mathrm{Ca}$ contents for acidic soils. However, this is not the case for CEC [24]. The relationships between exchangeable cation contents and site index were more often significant compared to the synoptic variables mentioned above (Tab. II). The variables $\log (\mathrm{Ca}), \log (\mathrm{Mg})$ and $\log (\mathrm{S})$ were the best predictors of $\mathrm{SI}_{100}$, providing parabolic models with flat convexity. Growth reduction was more pronounced for high values than for low ones because residuals were less spread for high values. 
Table II. Results of the simple or polynomial regressions between $\mathrm{SI}_{100}$ and different soil, climate and topography variables for the whole sample and for soils with or without a carbonated horizon. Chemical soil variables were measured on A-horizon. The variables for the whole sample are given in ascending order of $R^{2}$.

\begin{tabular}{|c|c|c|c|c|}
\hline \multirow{2}{*}{\multicolumn{2}{|c|}{$\begin{array}{l}\text { Variable Model equation } \\
\text { Whole sample }(n=99)\end{array}$}} & \multirow{3}{*}{$\begin{array}{c}R^{2} \\
0.056\end{array}$} & \multirow{3}{*}{$\begin{array}{l}p>F \\
0.018\end{array}$} & \multirow{3}{*}{$\begin{array}{c}\mathrm{SE}(\mathrm{m}) \\
4.46\end{array}$} \\
\hline & & & & \\
\hline \multirow[t]{2}{*}{ Aspect } & $\mathrm{SI}_{100}=25.4+2.65$ (Aspect) & & & \\
\hline & Plots where slope $\geq 4 \%(n=47): \mathrm{SI}_{100}=26.6+2.88$ (Aspect) & 0.157 & 0.0059 & 4.04 \\
\hline $\mathrm{pH}-\mathrm{H}_{2} \mathrm{O}$ & $\mathrm{SI}_{100}=-8.5+14.49\left(\mathrm{pH}-\mathrm{H}_{2} \mathrm{O}\right)-1.52\left(\mathrm{pH}-\mathrm{H}_{2} \mathrm{O}\right)^{2}$ & 0.068 & 0.034 & 4.45 \\
\hline $\log (\mathrm{K})$ & $\mathrm{SI}_{100}=20.9-19.93(\log (\mathrm{K}))-16.82(\log (\mathrm{K}))^{2}$ & 0.110 & 0.0034 & 4.35 \\
\hline $\mathrm{Mg} / \mathrm{K}$ & $\mathrm{SI}_{100}=23.1+2.30(\mathrm{Mg} / \mathrm{K})-0.415(\mathrm{Mg} / \mathrm{K})^{2}$ & 0.126 & 0.0015 & 4.31 \\
\hline Topo & $\mathrm{SI}_{100}=21.7+0(\mathrm{G}<\mathrm{L})+3.81(\mathrm{G}=\mathrm{L})+6.51(\mathrm{G}>\mathrm{L})$ & 0.129 & 0.0013 & 4.30 \\
\hline $\mathrm{S} / \mathrm{T}$ & $\mathrm{SI}_{100}=20.9+25.25(\mathrm{~S} / \mathrm{T})-23.0(\mathrm{~S} / \mathrm{T})^{2}$ & 0.134 & 0.001 & 4.30 \\
\hline $\mathrm{pH}-\mathrm{KCl}$ & $\mathrm{SI}_{100}=-13.8+19.90(\mathrm{pH}-\mathrm{KCl})-2.42(\mathrm{pH}-\mathrm{KCl})^{2}$ & 0.150 & 0.0003 & 4.25 \\
\hline $\mathrm{K} / \mathrm{P}_{2} \mathrm{O}_{5}$ & $\mathrm{SI}_{100}=29.9-1.52\left(\mathrm{~K} / \mathrm{P}_{2} \mathrm{O}_{5}\right)$ & 0.160 & $<0.0001$ & 4.21 \\
\hline $\log (\mathrm{S})$ & $\mathrm{SI}_{100}=26.4+4.14(\log (\mathrm{S}))-5.34(\log (\mathrm{S}))^{2}$ & 0.210 & $<0.0001$ & 4.10 \\
\hline $\log (\mathrm{Mg})$ & $\mathrm{SI}_{100}=26.3-6.42(\log (\mathrm{Mg}))-8.32(\log (\mathrm{Mg}))^{2}$ & 0.213 & $<0.0001$ & 4.09 \\
\hline $\log (\mathrm{Ca})$ & $\mathrm{SI}_{100}=27.3+1.37(\log (\mathrm{Ca}))-3.99(\log (\mathrm{Ca}))^{2}$ & 0.220 & $<0.0001$ & 4.07 \\
\hline SWC $0-150$ & $\mathrm{SI}_{100}=20.3+0.032(\mathrm{SWC} 0-150)$ & 0.247 & $<0.0001$ & 3.98 \\
\hline Humus form & $\begin{aligned} \mathrm{SI}_{100}= & 22.1+0(\text { Dysmoder-Mor })+4.86(\text { Eumoder })+6.29 \text { (Oligomull to hemimoder }) \\
& +5.29(\text { Mesomull })+1.44(\text { Eumull })\end{aligned}$ & 0.312 & $<0.0001$ & 3.87 \\
\hline \multicolumn{5}{|c|}{ Soils with a carbonated horizon $(n=30)$} \\
\hline $\log (\mathrm{Ca})$ & $\mathrm{SI}_{100}=28.5-4.86(\log (\mathrm{Ca}))$ & 0.260 & 0.004 & 3.35 \\
\hline $\mathrm{K} / \mathrm{P}_{2} \mathrm{O}_{5}$ & - & - & - & - \\
\hline $\mathrm{Ca} / \mathrm{Mg}$ & $\mathrm{SI}_{100}=26.1-0.27(\mathrm{Ca} / \mathrm{Mg})$ & 0.157 & 0.029 & 3.58 \\
\hline \multirow[t]{2}{*}{$\mathrm{Mg} / \mathrm{K}$} & $\mathrm{SI}_{100}=29.9-0.85(\mathrm{Mg} / \mathrm{K})$ & 0.143 & 0.039 & 3.61 \\
\hline & $\mathrm{SI}_{100}=30.4-0.34(\mathrm{Ca} / \mathrm{Mg})-1.09(\mathrm{Mg} / \mathrm{K})$ & 0.381 & 0.0015 & 3.12 \\
\hline \multicolumn{5}{|c|}{ Soils without any carbonated horizon $(n=69)$} \\
\hline $\log (\mathrm{Ca})$ & $\mathrm{SI}_{100}=27.6-3.88(\log (\mathrm{Ca}))+1.99(\log (\mathrm{Ca}))^{2}$ & 0.186 & 0.0011 & 4.46 \\
\hline $\mathrm{K} / \mathrm{P}_{2} \mathrm{O}_{5}$ & $\mathrm{SI}_{100}=31.8-2.15\left(\mathrm{~K} / \mathrm{P}_{2} \mathrm{O}_{5}\right)$ & 0.225 & $<0.0001$ & 4.22 \\
\hline $\mathrm{Ca} / \mathrm{Mg}$ & - & - & - & - \\
\hline $\mathrm{Mg} / \mathrm{K}$ & - & - & - & - \\
\hline
\end{tabular}

Lastly, $\mathrm{SI}_{100}$ was not correlated with $\mathrm{C} / \mathrm{N}$ ratio, decreased with increasing $\mathrm{K} / \mathrm{P}_{2} \mathrm{O}_{5}$ and displayed a parabolic, convex response to $\mathrm{Mg} / \mathrm{K}$.

Regressions for each soil type (with and without a carbonated horizon) between $\mathrm{SI}_{100}$ and several nutrient descriptors (Tab. II and Fig. 4) showed that soil types could be distinguished on the graph representing $\mathrm{SI}_{100}$ as a function of $\log (\mathrm{Ca}) . \mathrm{SI}_{100}$ decreased with increasing $\log (\mathrm{Ca})$ on soils with a carbonated horizon. However, the other soil types still showed a curvilinear relationship between $\mathrm{SI}_{100}$ and $\log (\mathrm{Ca})$. $\mathrm{SI}_{100}$ decreased with increasing $\mathrm{Ca} / \mathrm{Mg}$ and $\mathrm{Mg} / \mathrm{K}$ only on soils with a carbonated horizon (Tab. II). In contrast, $\mathrm{SI}_{100}$ decreased with increasing $\mathrm{K} / \mathrm{P}_{2} \mathrm{O}_{5}$ only on soils without any carbonated horizon.

\subsection{Additive effects of ecological variables on site index}

\subsubsection{East region ( $\mathrm{E} 1$ à $\mathrm{E} 4)$}

The models contained either 2 or 3 predictors (Tab. III). Climatic water balance (PET-P) had a negative effect and SWC 0 -150 had a positive effect on $\mathrm{SI}_{100}(\mathrm{E} 1)$. Topographic position had an additive effect on $\mathrm{SI}_{100}$ which increased by $5.2 \mathrm{~m}$ from a deficit position to a neutral position and increases further by $1.1 \mathrm{~m}$ in a favourable position. $\mathrm{SI}_{100}$ was optimum when $\mathrm{S}$ was between 1.08 and $1.35 \mathrm{cmol}^{+} / \mathrm{kg}$ (E2-E3) or when $\mathrm{Mg}$ was $0.41 \mathrm{cmol}^{+} / \mathrm{kg}$ (E4). $\mathrm{SI}_{100}$ was optimum when humus form was mesomull (E3-E4) and higher on eumull compared to eumoder. The best models in this region explained $74 \%$ of site index variance (E3 and E4). 
Table III. Results of the stepwise multiple regressions of $\mathrm{SI}_{100}$ according to site variables. Models are adjusted for Eastern $(n=52)$, Western $(n=47)$ and both regions $(n=99)$. The table gives model number, equation, $R^{2}$ and standard error (SE).

\begin{tabular}{|c|c|c|c|}
\hline Code & Model equation & $R^{2}$ & $\mathrm{SE}(\mathrm{m})$ \\
\hline E1 & $\mathrm{SI}_{100}=27.0+0.037(\mathrm{SWC} 0-150)-0.059(\mathrm{PET}-\mathrm{P})-1.10\left(\mathrm{~K} / \mathrm{P}_{2} \mathrm{O}_{5}\right)$ & 0.457 & 3.71 \\
\hline E2 & $\mathrm{SI}_{100}=23.1+0(\mathrm{G}<\mathrm{L})+5.2(\mathrm{G}=\mathrm{L})+6.3(\mathrm{G}>\mathrm{L})+4.03(\log (\mathrm{S}))-6.65(\log (\mathrm{S}))^{2}$ & 0.542 & 3.43 \\
\hline E3 & $\begin{aligned} \mathrm{SI}_{100}= & 18.9+0.71(\log (\mathrm{S}))-4.48(\log (\mathrm{S}))^{2}+0(\text { Dysmoder}-M o r)+5.95(\text { Eumoder })+10.84(\text { Oligomull to Hemimoder }) \\
& +11.18(\text { Mesomull })+9.61(\text { Eumull })\end{aligned}$ & 0.744 & 2.63 \\
\hline E4 & $\begin{aligned} \mathrm{SI}_{100}= & 13.61+0.022(\mathrm{SWC} 0-150)-7.15(\log (\mathrm{Mg}))-4.00(\log (\mathrm{Mg}))^{2}+0(\text { Dysmoder-Mor })+4.12 \text { (Eumoder) } \\
& +9.10(\text { Oligomull to Hemimoder })+10.31(\text { Mesomull })+7.92(\text { Eumull })\end{aligned}$ & 0.744 & 2.66 \\
\hline W1 & $\begin{aligned} \mathrm{SI}_{100}= & \left.25.0+0.025(\mathrm{SWC} 0-150)-1.62\left(\mathrm{~K} / \mathrm{P}_{2} \mathrm{O}_{5}\right)+0(\text { Dysmoder-Mor })+3.31 \text { (Eumoder }\right) \\
& +3.37 \text { (Oligomull to Hemimoder })+3.54(\text { Mesomull })-1.62(\text { Eumull })\end{aligned}$ & 0.506 & 3.17 \\
\hline W2 & $\begin{aligned} \mathrm{SI}_{100}= & \left.24.4+0.031(\mathrm{SWC} 0-150)-3.06(\log (\mathrm{Mg}))-10.10(\log (\mathrm{Mg}))^{2}-1.65(\mathrm{Mg} / \mathrm{K})+0 \text { (Dysmoder-Mor }\right) \\
& +3.39(\text { Eumoder })+3.87(\text { Oligomull to Hemimoder })+4.95(\text { Mesomull })+5.81 \text { (Eumull })\end{aligned}$ & 0.625 & 2.83 \\
\hline $\mathrm{T} 1$ & $\begin{aligned} \mathrm{SI}_{100}= & 23.0+0.022(\mathrm{SWC} 0-150)+0(\mathrm{G}<\mathrm{L})+1.8(\mathrm{G}=\mathrm{L})+3.9(\mathrm{G}>\mathrm{L})-5.76(\log (\mathrm{Mg}))-6.59(\log (\mathrm{Mg}))^{2} \\
& -0.764\left(\mathrm{~K}^{2} \mathrm{P}_{2} \mathrm{O}_{5}\right)\end{aligned}$ & 0.491 & 3.36 \\
\hline $\mathrm{T} 2$ & $\begin{aligned} \mathrm{SI}_{100}= & 19.2+0.026(\mathrm{SWC} 0-150)-5.39(\log (\mathrm{Mg}))-6.13(\log (\mathrm{Mg}))^{2}+0(\text { Dysmoder}-M o r)+3.82(\text { Eumoder }) \\
& +4.82(\text { Oligomull to Hemimoder })+4.86(\text { Mésomull })+1.40(\text { Eumull })\end{aligned}$ & 0.600 & 3.00 \\
\hline $\mathrm{T} 3$ & $\begin{aligned} \mathrm{SI}_{100}= & 21.7+0.019(\mathrm{SWC} 0-150)+3.70(\log (\mathrm{S}))-3.96(\log (\mathrm{S}))^{2}-0.70(\mathrm{Mg} / \mathrm{K})+0(\text { Dysmoder}-M o r) \\
& +4.16(\text { Eumoder })+5.31(\text { Oligomull to Hemimoder })+5.45(\text { Mésomull })+1.72(\text { Eumull })\end{aligned}$ & 0.596 & 3.03 \\
\hline
\end{tabular}

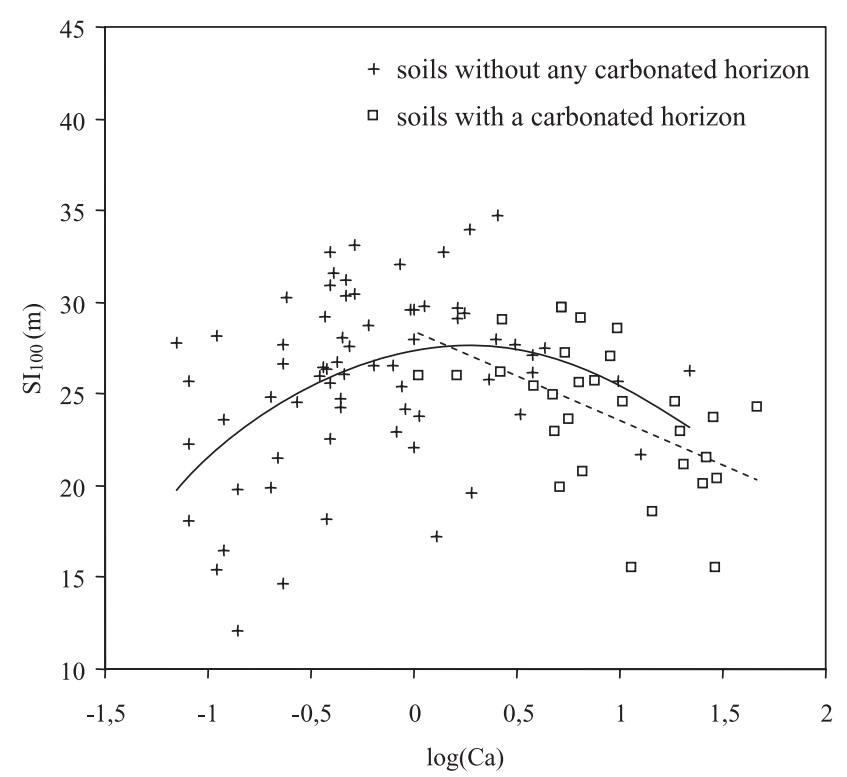

Figure 4. Relationships between $\mathrm{SI}_{100}$ and exchangeable $\mathrm{Ca}$ in the A-horizon according to soil type (with and without a carbonated horizon) and corresponding regression lines.

\subsubsection{West region (W1 to W3)}

The models had less predictive power than in the East region and contained 3 or 4 predictors. The predictors were almost the same: SWC 0-150, $\mathrm{K} / \mathrm{P}_{2} \mathrm{O}_{5}, \log (\mathrm{Mg})$, humus form. $\log (\mathrm{S})$ had no significant effect in this region. No climatic or topographic parameters were better predictors than SWC 0-150 and none could be significantly added to SWC $0-150 . \mathrm{SI}_{100}$ was optimum when $\mathrm{Mg}$ was $0.86 \mathrm{cmol}^{+} / \mathrm{kg}$ (W2). The effect of humus form varied according to the model: eumull was the worst class in model W1 whereas it was one of the best in model W2; the order was the same in the two models for the other humus classes.

\subsubsection{Global models (T1 to T3)}

Models had 3 or 4 predictors and $R^{2}$ values were intermediate compared to regional models. Models based on (PETP) + (SWC 0-150) were no better than models based on SWC $0-150$ only and SWD gave no better models than the ones based on SWC 0-150. Topographic position was the only parameter that explained a significant part of variance in addition to SWC $0-150 . \mathrm{SI}_{100}$ was optimum when $\mathrm{S}$ was $1.60 \mathrm{cmol}^{+} / \mathrm{kg}$ (T3) or when $\mathrm{Mg}$ was about $0.64 \mathrm{cmol}^{+} / \mathrm{kg}$ (T1 or T2). The most favourable humus forms for $\mathrm{SI}_{100}$ were mesomull and oligomull-to-hemimoder and the most unfavourable humus forms were dysmodermor and eumull. Moreover, no significant regional effect was detected in these three models.

We also tested for an interaction between SWC and nutrient factors. A two-way ANOVA of $\mathrm{SI}_{100}$ according to SWC class (3 balanced classes) and the presence or absence of a carbonated horizon in the soil profile (whatever the depth of the reaction to $\mathrm{HCl}$ ) indicated that only the SWC class was significant. A twoway ANOVA testing the additive effect of the SWC class ( 3 classes) and humus form showed that only the main factors were significant.

\subsection{Respective part of water and nutrient budgets in predicting site index variations}

The climate/water-related factors and nutrient-related factors explained 0 to $25 \%$ and 9 to $74 \%$ of the variance in site index, respectively (Tab. IV). For global models (T1 to T3), the climate/water-related factors and nutrient-related factors explained 6 to $16 \%$ and 20 to $35 \%$ of the variance in site index, respectively. The confounding effect accounted for $13 \%$ to $19 \%$ of the variance. 
Table IV. Partition of total variance of models E1 to T3 according to: (1) sums of squares (SS) of climate/water-related factors; (2) SS (nutrient-related factors); (3) SS (confounding effect of (1) and (2)); (4) residual variance.

\begin{tabular}{|c|c|c|c|c|c|c|c|c|c|}
\hline Sums of squares & E1 & E2 & E3 & E4 & W1 & W2 & $\mathrm{T} 1$ & $\mathrm{~T} 2$ & $\mathrm{~T} 3$ \\
\hline Climate/water-related factors & $25 \%$ & $18 \%$ & $0 \%$ & $7 \%$ & $19 \%$ & $13 \%$ & $16 \%$ & $12 \%$ & $6 \%$ \\
\hline Nutrient-related factors & $9 \%$ & $31 \%$ & $74 \%$ & $45 \%$ & $19 \%$ & $43 \%$ & $20 \%$ & $35 \%$ & $35 \%$ \\
\hline Confounding effect of factors & $12 \%$ & $5 \%$ & $0 \%$ & $23 \%$ & $0.2 \%$ & $7 \%$ & $13 \%$ & $13 \%$ & $19 \%$ \\
\hline Residual variance & $54 \%$ & $46 \%$ & $26 \%$ & $26 \%$ & $61 \%$ & $37 \%$ & $51 \%$ & $40 \%$ & $40 \%$ \\
\hline
\end{tabular}

\section{DISCUSSION}

\subsection{Feasibility of a large-scale autecological study: the role of the sampling strategy}

The different multiple regression models explained between 49 and $60 \%$ of site index variance in the global models (Tab. III). Predictions were better in the Eastern region but predictors in regional models remained largely consistent with global models and only differed for climatic and topographic variables and quantitative response to nutrient gradient. These values were consistent with $R^{2}$ obtained for sessile oak in the Tronçais National Forest (50-61\% of variance in site index, see [46]), even if our spatial scale was larger. Consequently, our results do not support the hypothesis that increasing spatial scale will decrease site index prediction quality [23, 29]. Our conclusion is that autecological studies on broadleaved species in lowland forests could be viable on an inter-regional scale, which would considerably reduce the costs. However, we emphasize the need for well-designed sampling: it is necessary to achieve a complete, balanced sampling design stratified according to the main ecological gradients (or to sample regularly along these gradients), and to select pure, even-aged and closed high-forest stands as far as possible. Common as well as marginal site conditions must be sampled with the same intensity and, since marginal site conditions are sparse, sampling efforts must be largely devoted to finding those sites.

\subsection{Autecology of sessile oak}

\subsubsection{Role of soil water capacity and topographic position}

Maximum soil water capacity played an important role; it was necessary to apply a costly, original protocol to test its effect. The influence of soil water capacity on sessile oak height and radial growth had already been frequently demonstrated but more often for radial growth [19, 32, 54, 57]. Nieminen [61] mentioned a correlation of 0.40 between sessile oak height growth and soil water capacity on silt and marl soils. Jacquemin et al. [46] indicated that site index at 100 years increases by $2 \mathrm{~m}$ with a $100 \mathrm{~mm}$ increase in soil water capacity. This is close to our estimate, even if their result was obtained with a more simple sampling protocol than the one in our study.

The effect of topography on site index was consistent with the effect of soil water capacity: the difference between favourable and unfavourable positions $(3.9 \mathrm{~m}$, model $\mathrm{T} 1)$ corresponded to a difference of $175 \mathrm{~mm}$ in SWC 0-150, which is very important. Our results were consistent with Jacquemin et al.
[46] who mentioned a 2-m decrease in site index for unfavourable topography compared to other positions, but samples for opposite positions are missing in their data.

\subsubsection{Role of climatic factors and soil water deficit}

Site index was influenced by aspect but only in simple models (Tab. II). This result was surprising for such a moderate relief; however, it confirms the role of aspect on sessile oak height growth [46].

Other climatic factors (PET-P, SWD) had a very limited influence on sessile oak height growth that was restricted to eastern models (E1) and was not significant in global models (T1 to T3). We found that soil water deficit was a worse predictor compared to soil water capacity. Our results were not consistent with other findings that are generally established on radial growth using a dendroclimatic analysis [19, 53]. Indeed, different studies have shown that sessile oak annual radial increment is positively influenced by warm temperatures during the growing season or at the beginning of the summer [11, $56,63]$ and also by precipitation accumulated over the growing season $[9,11,52,63]$. Water balance has been found to be a limiting factor for radial growth in sessile oak $[19,53]$. However, these studies have concerned radial growth and not height growth and do not analyse the role of climate at the same level: dendroclimatic studies test the effect of climate on year-to-year growth variations (using growth data averaged over 100 to 200 trees) whereas autecological studies test the influence of regional climate on plot-to-plot growth variations (using climatic data averaged over 30 years). Bréda and Pieffer [19] have provided an example of the decrease in the correlation between growth and soil water deficit from temporal to spatial scale for the same sample: the plot-to-plot correlation between soil water deficit and radial growth averaged over the 1964-1994 period is lower than year-to-year correlation between soil water deficit and radial growth averaged over all plots. A significant annual climatic effect on ring width is also observed on the data used in the present article by Bergès [14]. The difference between temporal and spatial growth responses to climate could be explained by the lower local climate variability compared to the annual climatic variability, but this was not the case in our data: the between-years standard deviation of mean annual temperature was $0.6^{\circ} \mathrm{C}$ over the $1961-1990$ period for Nancy, but the between-plots standard deviation was higher $\left(1.0^{\circ} \mathrm{C}\right.$, see Tab. I); the between-years standard deviation of annual precipitation was $136 \mathrm{~mm}$ over the 1961-1990 period for Nancy and the between-plots standard deviation was slightly lower $(114 \mathrm{~mm})$. The difference between temporal and spatial growth responses 
to climate should be clarified because no difference between the range of two ecological gradients was detected.

\subsubsection{Role of nutrient richness}

The flat, parabolic response of sessile oak height growth to soil acidity was consistent with the results of Jacquemin et al. [46] but we explored a larger nutrient gradient. These authors only considered mor to oligomull humus forms and observed that sessile oak site index is much lower on mor and dysmoder compared to eumoder, hemimoder and oligomull humus forms ( -9 and $-6 \mathrm{~m}$ respectively). Different authors have also observed a lower site index on very acidic sites and near-surface calcareous soils compared to intermediate conditions [32, 43, 62]. We found, as did Jacquemin et al. [46], that site index can be high on acidic-to-neutral soils (eumoder to mesomull), whereas the studies cited above observed an optimum restricted to slightly acidic sites with dysmull humus [27,32] or more neutral sites with mesomull humus [1]. Regional differences might explain this variation since both Dupouey and Cuiller and Mériaux [27, 32] worked in Alsace (north-eastern France) and Abt [1] in the Orléans National Forest (western France). However, we observed a different trend with an optimum site index close to acidic sites in the West and close to neutral sites in the East.

In our study, site index response to specific chemical soil variables was consistent with previous results, and the role of potassium and phosphorous nutrition in tree growth was highlighted. Indeed, $\mathrm{K} / \mathrm{P}_{2} \mathrm{O}_{5}$ for soils without any carbonated horizon had already been cited as a good indicator of soil mineral fertility for sessile oak stands in 3 forests in the "ligérien" geographic sector (Allogny, Blois, Bercé) [55]. An immediate increase in the radial growth of sessile oak of $40 \%$ (one year after $\mathrm{CaO}$ fertilisation by gypsum or lime) in a 40 - to 50 -yearold sessile oak coppice on poor acidic soil is mentioned by Bakker et al. [4]. Liming in moderate doses on sites showing nutrient deficiencies can stimulate the absorption capacity of the sessile oak root system by enlarging fine roots and thereby improving uptake of mineral nutrients and stand growth [4].

No effect of $\mathrm{C} / \mathrm{N}$ ratio on site index was detected, despite its classical use as an indicator of nitrogen availability for plants [3]. This ratio is probably not an accurate variable for nitrogen supply because it is not very well correlated to humus form $\left(R^{2}=0.35\right)$. Fertilisation experiments on adult and young trees have also stressed the importance of soil nitrogen, phosphorous and calcium supplies for sessile oak radial and height growth and foliar nutrient composition $[4,9,16,36]$. However, most of the experiments are carried out on nutrient-deficient soils where soil acidification is known to be detrimental to root growth and nutrient uptake [5]. It has also been shown that the application of liming on oak stands has an indirect, positive influence on nitrogen and carbon dynamics [12].

Nutritional problems on calcareous soils are not very welldocumented for sessile oak [13]. Oak seedling response to nitrogen fertilisation is positive for acidic soils and calcareous soils but more pronounced on a substrate with low nutrient supply. Moreover, $\mathrm{N}$ input can cause $\mathrm{N}$-induced nutritional imbalance for base cations on substrates with high nutrient supply [13]. The presence of calcium carbonate in the soil is known to negatively affect tree growth because it can reduce nitrogen and phosphorous nutrition quality [3]; it can also lead to impaired nutrient uptake for $\mathrm{Mg}$ and $\mathrm{K}$ as the adsorption complex is saturated by $\mathrm{Ca}$ in calcareous soils [15]. The last effect may be more important for sessile oak growth because $\mathrm{Mg} / \mathrm{K}$ and $\mathrm{Ca} /$ $\mathrm{Mg}$ had an additive, negative effect on soils with a carbonated horizon: the balance between $\mathrm{Ca}$ and $\mathrm{Mg}$ is critical but so is the balance between $\mathrm{Mg}$ and $\mathrm{K}$.

\subsubsection{Interaction between climate, soil water and nutrient factors and respective portion of variance in site index explained by the different ecological factors}

We tested the hypothesis that deeper soil horizons with calcium carbonate could not be prospected by the root system and so the water they contain could not be used by the tree. To do this, we explored site index response to soil water capacity on soils with a carbonated horizon. Our result did not confirm the hypothesis that calcium carbonate was more limiting for a large SWC than for a small SWC.

Most site index variance was related to local soil factors and corroborated the hypothesis that sessile oak growth was regulated by the combined influence of soil water and nutrient budgets. Most of the autecological studies already mentioned adopt a synoptic approach based on a pre-established forest site classification, and the effects of SWC and nutrient status on site index are difficult to separate (the most acidic or calcareous sites tend to have the shallowest soils). The additive effect of soil water capacity and nutrient status is observed when the authors compare dry with fresh sites for a given nutrient supply $[32,33,50]$. For example, Lainez [50] mentioned that the mean height of dominant trees in coppice-with-standards stands is lower on meso-acidic sites where mean soil water capacity is $108 \mathrm{~mm}$ compared to sites where soil water capacity is $158 \mathrm{~mm}$ $(21.2 \mathrm{~m}$ versus $25.8 \mathrm{~m})$. Our results clearly indicated that nutrient-related factors accounted for a higher portion of variance than climate/water-related ones. However, the relatively high proportion of variance that corresponded to the confounding climate/water/nutrient-related factors effects highlights the difficulty we had in completely separating the two main gradients, in spite of the sampling effort.

\subsubsection{Management implications}

These results can be translated into practical recommendations to forest managers for selecting suitable site conditions for sessile oak and forecasting accurate timber yield. This species should not be planted or naturally regenerated on sites with a very low mineral supply and/or a low soil water capacity, especially when these conditions are exacerbated by a deficit topographic position (water lateral loss $>$ gain). Although a dry climate and a south-western aspect are likely to limit site index, these two factors have a limited effect. This is consistent with the results of Lévy et al. on radial growth [56]. However, regular thinning can help to minimize water competition between trees and reduce the duration and intensity of droughts [18]. Additional work should investigate the effect of regional climate and waterlogging on sessile oak growth and validate the results obtained in previous studies $[7,56,58]$. 
Acknowledgements: This work was supported by a Convention linking the French Ministry of Agriculture (DERF) and the Cemagref entitled "Relationships between site, growth and wood quality of indigenous oaks" No. 01.40.07/95. We are sincerely grateful to G. Grandjean for his precious help during the sampling of various forest site conditions, J.C. Gégout for collecting floristic data, B. Jabiol for suggestions concerning soil descriptions and chemical analyses, A. Perrin and J.C. Rat for their technical help during increment core collection. We would also like to thank the French National Forest Office (ONF) for its technical help during this project, especially P. Duplat (ONF) for his invaluable comments during the study. We are grateful to the private owners and the ONF who gave us permission to work inside their forests and to core the trees. Special thanks to Victoria Moore for revising the English of the manuscript. The authors also wish to thank the two anonymous reviewers for helpful comments and suggestions on the manuscript.

\section{REFERENCES}

[1] Abt D., Contribution à l'étude des stations en Forêt d'Orléans, ENITEF, 1983.

[2] Baize D., Jabiol B., Guide pour la description des sols, INRA, Paris, 1995.

[3] Baize D., Guide des analyses courantes en pédologie, INRA, Paris, 1988.

[4] Bakker M.R., Nys C., Picard J.F., The effects of liming and gypsum applications on a sessile oak (Quercus petraea (M.) Liebl.) stand at La Croix-Scaille (French Ardennes) I. Site characteristics, soil chemistry and aerial biomass, Plant Soil 206 (1999) 99-108.

[5] Bakker M.R., Nys C., Effect of liming on fine root cation exchange sites of oak, J. Plant Nutr. 22 (1999) 1567-1575.

[6] Bary-Lenger A., Boinon M., Guns A., Comment prédire la productivité de l'épicéa commun (Picea abies Karst.) dans les forêts ardennaises, Silva Belgica 102 (1995) 9-16.

[7] Becker M., Levy G., Lefevre Y., Radial growth of mature pedunculate and sessile oaks in response to drainage, fertilization and weeding on acid pseudogley soils, Ann. For. Sci. 53 (1996) 585-594.

[8] Becker M., Lévy G., Le point sur l'écologie comparée du chêne sessile et pédonculé, Rev. For. Fr. 42 (1990) 148-154.

[9] Becker M., Nieminen T.M., Gérémia F., Short-term variations and long-term changes in oak productivity in northeastern France. The role of climate and atmospheric $\mathrm{CO}_{2}$, Ann. For. Sci. 51 (1994) $477-$ 492.

[10] Becker M., Influence relative du climat et du sol sur les potentialités forestières en moyenne montagne. Exemple des sapinières à fétuque (Festuca silvatica Vill.) dans les Vosges alsaciennes, Ann. Sci. For. 39 (1982) 1-31.

[11] Bednarz Z., The influence of temperature and precipitation on ring widths of oak (Quercus robur L.) in the Niepolomice forest near Cracow, southern Poland, Tree Ring Bull. 50 (1990) 1-10.

[12] Belkacem S., Nys C., Consequences of liming and gypsum topdressing on nitrogen and carbon dynamics in acid forest soils with different humus forms, Plant Soil 173 (1995) 79-88.

[13] Berger T.W., Glatzel G., Response of Quercus petraea seedlings to nitrogen fertilization, For. Ecol. Manage. 149 (2001) 1-14.

[14] Bergès L., Variabilités individuelle et collective de la croissance et de la densité du bois de Quercus petraea (Matt.) Liebl. en relation avec les facteurs écologiques, ENGREF, Nancy, 1998.

[15] Bonneau M., Fertilisation des forêts dans les pays tempérés, École Nationale du Génie Rural, des Eaux et des Forêts (ENGREF), Nancy, France, 1995.

[16] Bonneau M., Sessile oak seedling fertilization and leaf mineral composition in western France, Ann. For. Sci. 53 (1996) 605-613.

[17] Bréda N., Cochard H., Dreyer E., Granier A., Field comparison of transpiration, stomatal conductance and vulnerability to cavitation of Quercus petraea and Quercus robur under water stress, Ann. For. Sci. 50 (1993) 571-582.

[18] Bréda N., Granier A., Aussenac G., Effects of thinning on soil and tree water relations, transpiration and growth in an oak forest (Quercus petraea (Matt) Liebl.), Tree Physiol. 15 (1995) 295-306.

[19] Bréda N., Pieffer M., Étude du bilan hydrique des chênaies de la Forêt Domaniale de la Harth (Haut-Rhin) et impact des épisodes de sécheresse sur la croissance radiale des chênes, Rapport de Convention, INRA Unité d'Écophysiologie Forestière - Equipe Phytoécologie - ONF, Nancy, 1999.

[20] Bréda N., Analyse rétrospective de la croissance radiale des chênes de la Forêt Domaniale de La Harth (Haut-Rhin), Rapport de Convention, INRA Unité d'Écophysiologie Forestière - Équipe Phytoécologie, Nancy, 1998.

[21] Brêthes A., La typologie des stations forestières. Recommandations méthodologiques, Rev. For. Fr. 41 (1989) 7-27.

[22] Chen H.Y.H., Klinka K., Kabzems R.D., Site index, site quality, and foliar nutrients of trembling aspen: relationships and predictions, Can. J. For. Res. 28 (1998) 1743-1755.

[23] Chen H.Y., Krestov P.V., Klinka K., Trembling aspen site index in relation to environmental measures of site quality at two spatial scales, Can. J. For. Res. 32 (2002) 112-119.

[24] Ciesielski H., Sterckeman T., A comparison between three methods for the determination of cation exchange capacity and exchangeable cations in soils, Agronomie 17 (1997) 9-16.

[25] Claessens H., Pauwels D., Thibaut A., Rondeux J., Site index curves and autecology of ash, sycamore and cherry in Wallonia (Southern Belgium), Forestry 72 (1999) 171-182.

[26] Cochard H., Bréda N., Granier A., Aussenac G., Vulnerability to air embolism of three European oak species (Quercus petraea (Matt) Liebl, Q. pubescens Willd, Q. robur L.), Ann. For. Sci. 49 (1992) 225-233.

[27] Cuiller B., Mériaux P., Définition des stations forestières du Centre de Mulhouse, ENITEF, 1980.

[28] Curt T., Dole S., Marmeys G., Alimentation en eau et production forestière. Application d'indicateurs simples pour les résineux dans le Massif Central, Étude et Gestion des Sols 3 (1996) 81-96.

[29] D'Epenoux F., Influence du milieu sur la production forestière. Efficacité comparée de deux méthodes, Informations Techniques du Cemagref 95 (1994) 8.

[30] Duplat P., Tran-Ha M., Modelling the dominant height growth of sessile oak (Quercus petraea Liebl.) in France - Inter-regional variability and effect of the recent period (1959-1993), Ann. Sci. For. 54 (1997) 611-634.

[31] Duplat P., Indice de fertilité basé sur un modèle de croissance en hauteur, in: Buffet M., Girault D. (Eds.), Station forestière, production et qualité du bois : éléments méthodologiques, Cemagref, Nogent sur Vernisson, 1989, pp. 51-78.

[32] Dupouey J.L., Étude phytosociologique et écologique du massif de Haguenau (Bas-Rhin). Apports méthodologiques. Potentialités sylvicoles, INA Paris-Grignon, 1983.

[33] Farinotti S., Larousse J.F., Production et qualité des chênes en Sologne Bourbonnaise : vers une optimisation de la gestion des peuplements irréguliers, ENITEF, 1991.

[34] Franc A., Houllier F., Étude des relations entre milieu et production : quelques critères de choix de méthodes, in: Buffet M., Girault D. (Eds.), Station forestière, production et qualité des bois : éléments méthodologiques, Cemagref, Nogent-sur-Vernisson, 1989, pp. 13-49.

[35] Franc A., Le Massif Central cristallin. Analyse du milieu. Choix des essences, Cemagref, Clermont-Ferrand, 1989.

[36] Garbaye J., Bonneau M., Premiers résultats d'un essai de fertilisation sur plantation de chêne rouvre (Quercus sessiliflora), Ann. Sci. For. 32 (1975) 175-183. 
[37] Gégout J.C., Jabiol B., Analyses de sol en forêt : les choix du phytoécologue dans le cadre des typologies de stations ou des études scientifiques, Rev. For. Fr. 53 (2001) 568-580.

[38] Gilbert J.M., Chevalier R., Dumas Y., Autécologie du pin laricio de Corse dans le secteur ligérien, Rev. For. Fr. 48 (1996) 201-216.

[39] Gilbert J.M., Franc A., Typologie et cartographie du climat dans la moitié nord de la France. Perspectives d'utilisation en relations milieu-production forestière, Ingénieries EAT 12 (1997) 35-47.

[40] Gilbert J.M., Relier milieu et production des essences forestières : comparaison de deux approches, Ingénieries EAT 8 (1996) 31-39.

[41] Graham M.H., Edwards M.S., Statistical significance versus fit estimating the importance of individual factors in ecological analysis of variance, Oikos 93 (2001) 505-513.

[42] Grandjean G., Sigaud P., Contribution à la taxonomie et à l'écologie des chênes du Berry, Ann. Sci. For. 44 (1987) 35-66.

[43] Grandjean G., Chorologie et exigences écologiques de quelques espèces ligneuses forestières indigènes et introduites en France, ENGREF, 1991.

[44] Inventaire Forestier National, site web : http://www.ifn.fr/spip, 2004.

[45] Jabiol B., Baize D., Un nouveau langage en pédologie : le référentiel pédologique, Rev. For. Fr. 45 (1993) 141-152.

[46] Jacquemin B., Lacroix R., Démarcq P., Duplat P., Relation entre station et fertilité du chêne sessile (Quercus petraea Liebl.) en forêt de Tronçais, Bulletin Technique de l'ONF 39 (2000) 33-44.

[47] Jamagne M., Bétremieux R., Begon J.C., Morin A., Quelques données sur la variabilité dans le milieu naturel de la réserve en eau des sols, Bulletin Technique d'Information, 1977, pp. 324-325.

[48] Jarret P., Sylviculture du Chêne sessile, Bulletin Technique de l'ONF 31 (1996) 21-28.

[49] Kayahara G.J., Klinka K., Marshall P.L., Testing site index sitefactor relationships for predicting Pinus contorta and Picea engelmannii $\times P$. glauca productivity in central British Columbia, Canada, For. Ecol. Manage. 110 (1998) 141-150.

[50] Lainez D., Études préalables à l'aménagement des forêts communales du Massif de la Serre. Définition des stations forestières, ENITEF, 1981.

[51] Le Goff N., Lévy G., Productivité du frêne (Fraxinus excelsior L.) en région Nord-Picardie, Ann. Sci. For. 41 (1984) 135-170.
[52] Lebourgeois F., Cousseau G., Ducos Y., Étude d'une chênaie sessiliflore exceptionnelle : la futaie des Clos (Sarthe), Rev. For. Fr. 4 (2003) 333-346.

[53] Lebourgeois F., Cousseau G., Ducos Y., Climate-tree-growth relationships of Quercus petraea Mill. stand in the Forest of Bercé ("Futaie des Clos", Sarthe, France), Ann. For. Sci. 61 (2004) 361372.

[54] Lebourgeois F., Les Chênes sessile et pédonculé (Ouercus petraea Liebl. et Quercus robur L.) dans le réseau RENECOFOR : rythme de croissance radiale, anatomie du bois, de l'aubier et de l'écorce, Rev. For. Fr. 51 (1999) 522-536.

[55] Leroy P., Étude de nutrition-production sur le chêne. Perspectives de fertilisation, Rev. For. Fr. 20 (1968) 323-340.

[56] Lévy G., Becker M., Duhamel D., A comparison of the ecology of pedunculate and sessile oaks: radial growth in the centre and northwest France, For. Ecol. Manage. 55 (1992) 51-63.

[57] Lévy G., Delatour C., Becker M., Le dépérissement du chêne des années 1980 dans le Centre de la France, point de départ d'une meilleure compréhension de l'équilibre et de la productivité de la chênaie, Rev. For. Fr. 46 (1994) 495-503.

[58] Lévy G., Lefèvre Y., La forêt et sa culture sur sol à nappe temporaire, École Nationale du Génie Rural, des Eaux et des Forêts, Nancy, 2001.

[59] Lévy G., Appréciation de la fertilité du sol, Ann. Sci. For. 40 (1988) $11-18$.

[60] Lloyd W.L., Lemmon P.E., Rectifying azimuth (of aspect) in studies of soil-site index relationships, in: Youngberg C.T., Davey C.B. (Eds.), Tree growth and forest soils, Oregon State University Press, Corvallis, 1970, pp. 435-448.

[61] Nieminen T.M., Étude dendrochronologique du chêne (pédonculé et sessile) et du hêtre dans une forêt de la plaine lorraine, Faculté des Sciences, Nancy, 1988

[62] Picard J.F., Les types de station de la forêt domaniale de Bellême (Orne), Rev. For. Fr. 30 (1978) 425-431.

[63] Pilcher J.R., Gray B., The relationships between oak tree growth and climate in Britain, J. Ecol. 70 (1982) 297-304.

[64] Pritchett W.L., Fisher R.F., Properties and management of forest soils, 2nd ed., John Wiley and Sons, New York, 1987.

[65] Timbal J., Aussenac G., An overview of ecology and silviculture of indigenous oaks in France, Ann. Sci. For. 53 (1996) 649-661.

[66] Wang G.G., White spruce site index in relation to soil, understory vegetation, and foliar nutrients, Can. J. For. Res. 25 (1995) 29-38. 